\title{
AN ANALYSIS OF READING TEXTS
}

\author{
Desi Andriani \\ Fakultas Keguruan dan Ilmu Pendidikan (FKIP) Universitas Putra Indonesia YPTK Padang, Indonesia \\ desiandriani343@yahoo.com
}

\begin{abstract}
The reading materials were difficult to be comprehended by students. Therefore, this research focuses on analying the reading materials used by English teachers at SMA N 2 Sungai Tarab. The purposes of carrying this research are to find out the readability, exploitability, and content suitability of recount, narrative, and procedure texts. This is a descriptive research. Data were collected by using analysis format. Sources of data in this research were forty five texts that are used by teachers. To analyze the texts, writer used criteria of good texts for foreign language students. The criteria were readability, exploitability and content suitability. Every criterion has subindicators. The findings showed that the reading materials still have problem. It is proved by the findings which show that mostly reading materials have problem in length of the texts. Some of the reading materials have problem in lexical exploitability. The new vocabularies in the texts are not useful for the students. It means that the new vocabularies cannot be used by the students to comprehend other texts. Some of the texts have problem in interesting, up to date and gender sensitivity.
\end{abstract}

Keywords: Content suitability, Exploitabillity, Readability

\section{INTRODUCTION}

Listening, speaking, reading and writing are four skills of English. Those skills are important to be mastered without ignoring each other. For many students, reading is the most important skill in foreign language. As a skill, reading is clearly one of important language skills that students have to read English material for their subject. The students often think to be easier to obtain information from written text by reading. Furthermore, reading skill is related to reading materials. Reading materials are an important thing in learning process. The information is easier to be obtained through reading than listening. Reading materials also can give clear information to the students. Students do interaction in the class not only to the teachers, their friends but also to the reading materials.

Reading materials can be taken from textbook, magazine and other sources. Textbook plays an important thing in learning process. Richard (2001:251) points out that textbooks are key component of language teaching serving as the basis for much of the language input learners receive when learning a language. It is clear that the reading texts for learning process can be taken from the textbook by the English teacher. Due to the important of reading texts for education, Brown (1995:157) says that when teacher works with reading texts, it helps them to transfer knowledge through the reading texts. He also suggest there are three ways to find texts. They are through adopting, adapting and developing. Sariçoban as quoted by Ocak, et al (2010: 2) states that texts in a language class are a source of activity for students to practice and they improve a teacher's effectiveness. It means that students will get something after they read the reading text and it will change the role of the teachers. In order to give appropriate texts to the studdents, English teacher should pay attention to some factors. As suggested by Nuttal in Ling (2012:55), the factors are readability, exploitability and content suitability. 
Dale and Chall quoted by Kasule (2011:63) says that readability refers to ease or difficulty which the reading materials can be understood. Readability can be defined as the ability of texts to communicate the intention of writer to the intended readers. In addition, Fulcher (1997:498) states that readability or text difficulty is an area of concern for all who need to establish the appropriacy of a given text for a pedagogic purpose. In addition, according to Renkema (1995:175) readability is used to describe the combination of structural and lexical difficulty of a text, as well as referring to the amount of new vocabulary and any new grammatical forms present. Then, Kasule (2011:64) identifies four factors affecting readability. They are : first, content such as propositions, organization, chorerence. Second,style includes semantic and syntactic elements. Third, design includes typhography, format, and illustration. Last, structure such lay out.

Moreover there are some factors relate to readability as suggested by Day (2012:20). They are: lexical knowledge, bacground knowledge, syntactic appropriateness, discourse phenomena, organization and length of the text. Lexical knowledge has an important factor in measuring readability. Since the more unknown lexical items in a text, the students will be more difficult to comprehend the text. Hetherington (1985:42) also says that difficult word plays a major factor affecting difficulty of the texts. The more difficult words in a text,it will be more difficult students to understand the texts. In addition Chou (2011:108) also says that to comprehend the text well, it involves understanding the vocabulary, seeing relationship among words and concepts, organizing ideas, recognizing author's purpose.

Kendeou and Broek (2007:1567) also says that quality of lexical knowledge of readers will help them to comprehend the text well, the quality of lexical knowledge infleunces readers' comprehension of reading texts. Moreover, Liu and Nation in Hirsh and Nation (1992:690) the number of unknown lexical items in a text is about 1 word from 20 words. Students should comprehend the words $95 \%$. It means that if a text consists of 100 words, the new vocabulary is five words. In addition, Hirsh and Nation (1992:690) also state that if a reader knows 90\% of the running words in a text, then it will be 10 unknown words in every 100. If each line in the text contains about 10 words, then there will be one unknown word in every line. Reading will certainly be a struggle.

Along with lexical knowledge, background knowledge is also very important in the readability of a text. The more readers know about a particular topic, the more quickly and accurately they can read it. Lin (2002:173) says background knowledge plays a key role in the comprehension of a reading texts by students. Wyk and Greyling (2008:207) argue that key to comprehend text is background knowledge. Farrel quoted by Warsnak (1996:6) defines that background knowledge affects comprehension in three ways. First, it helps students make inferences about reading. Second, it directs attention to information that it is important in a knowledge domain. Last, background knowledge provides plan for recall. Moreover, Anderson and Pearson in Stahl et al (1991:2) say that background knowledge allows students to comprehend the texts through inferences, it relates specific information needs to understand a text. In conclusion, students need attention to get the specific information based on their background knowledge. 
Syntactic constructions in a text affects its readability. If a text contains grammatical constructions that the learners do not know, they might have a hard time reading it. According to Flesh in Arya et. al (2011:108), Flesch readability formula is the simple way to view syntactic complexity evident in readability. More complex sentence will be more difficult o understand. Complex sentence are more difficult to understand than short sentence. In addition Craint and Shankweilert (1986:199) argue that syntactic complexity is become a problem in compreheding a text. Huggins (1977:5) says that to know the syntactic complexity, students need to teach sentence from short sentence to complex sentence by the teachers. Similar to previous experts, Barrot (2004:5) also says that syntactic complexity also affects the text.

Day (1994:26) says that organization refers to both the rhetorical organization of the text and the clarity of the organization. Readers who can recognize the rhetorical organization of a text have better comprehension than those who do not. English steacher should carefully examine a text to see how it is organized. A text that is not well organized might present problems for students. Day (2012:22) says :textual phenomena at the level of discourse include the arrangement of topics and comments in a reading texts, and considerations of cohesiveness and coherence. English teachers need to be aware of the manner in which the author makes use of these in the texts and the degree to which students are able to deal with such textual phenomena.

The most common mistake of inexperienced teachers or teachers who are not able to judge the reading abilities of their students is to select a texts that is too long. If students are unable to finish the reading text, the lesson is not successful. The learners will be frustrated and often blame themselves, feeling that they are poor readers. According to Taylor in Sulistyorini (2006) says that as learning source, the text must have between 200 to 300 words. So the maximum number of words of a text is 300 words. In conclusion, the length of the text has also an important indicator of readability.

The second factor should be paid attention by English teacher is exploitability of the text. Exploitability means text should facilitate the development of reading skills in order to help reader become comprehensible. Nuttal as quoted by Ling et al (2012:55) say that selected texts should facilitate students to become an effective reader with the a bility refers to the ability to extract the content from the language that expresses it. Sasson (2007) states that not all texts offer an opportunity to their thematic, lexical, syntactic and structural appropriateness. Sasson (2007) argues that lexical exploitability refers to whether the texts offer opportunity to get some new vocabularies. In giving oppurtunity to students to get the new vocabulary, the text should be introduce it by using context clues. According to Wassman and Rinsky (2000:39-40) there are types of context clues are by using example, definition, cause effect, comparison contrast. In addition, Zainil (2008:5-10) adds another type of context clues. They are definition, example, cause and effect, constrast, restatement, modifier and sentence / paragraph. In conclusion, to introduce the meaning of new vocabulary, it can be used context clue such as definiftion, example, etc. Using context clues are to help students be easier to comprehend the text.

Structural exploitability means whether students can get meaning from the text. Grabe as quoted by Alyousef (2005:144) defines that to extract or to explore the meaning of reading can 
be through extensive and intensive reading. It means that it can be through buttom up or top down processing. When the students have background knowledge about the text, they will be able to explore their reading skill through the information that they know and information that they read. Sasson (2007) states that thematic exploitability refers to the moral issue that students can get after read the texts. So, moral issue is an important thing that should be gotten by the students. The last factor to choose appropriate text is content suitability of the text. Content suitability means text should be interesting and motivating. Moreover, reading materials shoud be match to learners' need. Nuttal in Ling et al (2012:55) say suitability of content of reading texts are interest to the students. Moreover, Hutchinson and Walters (1987:) say learners will have motivation to read texts when the texts are interested to them.

In addition Hidi (2001:191) states that interest has an important role in reader's text. In addition, Moser and Morrison (1998:234) suggest that "teachers ahould select reading materials that make students interest. Therefore they have enjoyment in reading. Hetherington $(1985: 44)$ also states that interest is used to measure the suitability of the reading materials. So, interest is the most important factor in making the content of the text is suitable to the students. Ebrahimi and Rahimi (2013:15) say that English teachers should be careful about the content of the materials. The content of the materials can affect students' motivation. In addition, McKay (2000:9) says that the content of materials should be suitable to the students' culture. She adds that the teachers should select the materials that suitable to the target culture or students' culture.

\section{METHOD}

The design of this study is descriptive analysis. Gay (2000) states that descriptive research determines and reports the ways thing are. It is told about something occurs in the field. Further, Gay adds there are two reasons why people use the descriptive method. First, a high percentage of reported research studies are descriptive in nature. Second, the descriptive method is useful for investigating a variety of educational problems. Since it was a descriptive research, the data was be collected through document of reading texts. The data in this research were reading texts used by English teachers to teach recount, narrative and recount texts. They are 45 texts (in appendix 1). The texts were from Erlangga textbook "Look Ahead" and adopted text.

The instrument was analysis format. It was used as the manual judge to measure the exploitability and content suitability of reading texts. To make the analysis format, researcher used theory Day (1994) for readability. The indicators were lexical knowledge, background knowledge, syntactic appropriateness, discourse phenomena, organization and length of the text. The theory for exploitability was proposed by Sassons (2007). The indicators of exploitability were lexical exploitability, structural exploitability and thematic exploitability. Suitability of content that proposed by Hidi (2001). The analysis format was used rating scale excellent, good, fair and poor (Munir, 2013:2).

\section{FINDINGS}

\section{Readability of Reading Materials}


For readability, the sub-indicators are lexical knowledge, background, syntactic appropriateness, discourse phenomena, organization and length of the text. The description of the data is below:

Table 1. Readability of Reading Materials

\begin{tabular}{|c|c|c|c|c|c|}
\hline No & $\begin{array}{l}\text { Type of } \\
\text { text }\end{array}$ & Sub-indicator & Mean & Category & $\begin{array}{l}\text { Number } \\
\text { of text }\end{array}$ \\
\hline \multirow{12}{*}{1} & \multirow{12}{*}{ Recount } & \multirow{2}{*}{ Lexical knowledge } & $3.51-4.00$ & Excellent & 1 text \\
\hline & & & $2.51-3.50$ & Good & 14 texts \\
\hline & & \multirow[t]{2}{*}{ Background knowledge } & $3.51-4.00$ & Excellent & 3 texts \\
\hline & & & $2.51-3.50$ & Good & 12 texts \\
\hline & & \multirow[t]{2}{*}{ Syntactic appropriateness } & $2.51-3.50$ & Good & 14 texts \\
\hline & & & $1.51-2.50$ & Adequate & 1 text \\
\hline & & \multirow[t]{2}{*}{ Organization } & $3.51-4.00$ & Excellent & 5 texts \\
\hline & & & $2.51-3.50$ & Good & 10 texts \\
\hline & & \multirow[t]{2}{*}{ Discourse phenomena } & $3.51-4.00$ & Excellent & 4 texts \\
\hline & & & $2.51-3.50$ & Good & 11 texts \\
\hline & & \multirow[t]{2}{*}{ Length of the text } & $2.51-3.50$ & Good & 5 texts \\
\hline & & & $1.51-2.50$ & Adequate & 10 texts \\
\hline \multirow[t]{23}{*}{2} & \multirow{10}{*}{$\begin{array}{l}\text { Narra } \\
\text { tive }\end{array}$} & Lexical knowledge & $2.51-3.50$ & Good & 15 texts \\
\hline & & Background knowledge & $2.51-3.50$ & Good & 15 texts \\
\hline & & Syntactic appropriateness & $2.51-3.50$ & Good & 15 texts \\
\hline & & \multirow[t]{2}{*}{ Organization } & $3.51-4.00$ & Excellent & 6 texts \\
\hline & & & $2.51-3.50$ & Good & 9 texts \\
\hline & & \multirow{2}{*}{ Discourse phenomena } & $3.51-4.00$ & Excellent & 5 texts \\
\hline & & & $2.51-3.50$ & Good & 10 texts \\
\hline & & \multirow[t]{3}{*}{ Length of the text } & $3.51-4.00$ & Excellent & 11 texts \\
\hline & & & $2.51-3.50$ & Good & 1 texts \\
\hline & & & $1.51-2.50$ & Adequate & 3 texts \\
\hline & \multirow{13}{*}{$\begin{array}{l}\text { Proce } \\
\text { dure }\end{array}$} & \multirow[t]{3}{*}{ Lexical knowledge } & $3.51-4.00$ & Excellent & 1 text \\
\hline & & & $2.51-3.50$ & Good & 12 texts \\
\hline & & & $1.51-2.50$ & Adequate & 2 texts \\
\hline & & \multirow[t]{2}{*}{ Background knowledge } & $3.51-4.00$ & Excellent & 4 texts \\
\hline & & & $2.51-3.50$ & Good & 11 texts \\
\hline & & \multirow[t]{2}{*}{ Syntactic appropriateness } & $3.51-4.00$ & Excellent & 2 texts \\
\hline & & & $2.51-3.50$ & Good & 13 texts \\
\hline & & \multirow[t]{2}{*}{ Organization } & $3.51-4.00$ & Excellent & 3 texts \\
\hline & & & $2.51-3.50$ & Good & 12 texts \\
\hline & & \multirow[t]{2}{*}{ Discourse phenomena } & $3.51-4.00$ & Excellent & 2 texts \\
\hline & & & $2.51-3.50$ & Good & 13 texts \\
\hline & & \multirow[t]{2}{*}{ Length of the text } & $2.51-3.50$ & Good & 6 texts \\
\hline & & & $1.51-2.50$ & Adequate & 9 texts \\
\hline
\end{tabular}

Based on the table above, the readability of recount, narrative and procedure is excellent, good and adequate. It means that the reading materials are good enough to be used. Most of 
procedure and recount have problem in ub-indicator of length of the texts. Some of the texts are too short and do not fulfill the minimum number of words in a text. In general, the texts are readable for Senior High School grade X. Narrative text are more readable than procedure and recount.

\section{Exploitability of Reading Materials}

For exploitability, the sub-indicators are lexical exploitabiliy, structural exploitability and thematic exploitability. The description of the data is below:

Table 2. Exploitability of the Reading Materials

\begin{tabular}{llllll}
\hline No & $\begin{array}{l}\text { Type of } \\
\text { text }\end{array}$ & Sub-indicator & Mean & Category & Number of text \\
\hline 1 & Recount & Lexical exploitability & $2.51-3.50$ & Good & 8 texts \\
& & & $1.51-2.50$ & Adequate & 7 texts \\
& & Structural exploitability & $2.51-3.50$ & Good & 15 texts \\
& \multirow{2}{*}{ Narrative } & Lexical exploitability & $2.51-3.50$ & Good & 8 texts \\
& & & $1.51-2.50$ & Adequate & 7 texts \\
& & Structural exploitability & $2.51-3.50$ & Good & 15 texts \\
& & Thematic exploitability & $3.51-4.00$ & Excellent & 2 texts \\
& \multirow{2}{*}{3} & & $2.51-3.50$ & Good & 13 texts \\
& Procedure & Lexical exploitability & $2.51-3.50$ & Good & 3 texts \\
& & & $1.51-2.50$ & Adequate & 12 texts \\
& & & $2.51-3.50$ & Good & 15 exts \\
\hline
\end{tabular}

From the table above, the exploitability of the text is good enough. It means that the students can develop their reading skill through the text. Moreover, narrative and recount are the most exploitable. In lexical exploitability, the texts use vocabularies that can be used by students when they are reading other texts. In structural exploitability, recount and narrative have excellent structural. The structures are arranged well. Therefore, it can help students to comprehend the text. In addition, the moral messages of narrative texts are an important thing in narrative. In this category, narrative texts have valuable moral value that can be applied by students in their life.

\section{Content suitability of Reading Materials}

For content suitability, the sub-indicators are interesting, socio-culturally appropriate, gender sensitive, up to date, age-appropriate and real-life.. The data description is in the following table:

Table 3. Content Suitability of the Reading Materials

\begin{tabular}{llllll}
\hline No & $\begin{array}{l}\text { Type of } \\
\text { Text }\end{array}$ & Sub-indicators & Mean & Category & $\begin{array}{l}\text { Number of } \\
\text { text }\end{array}$ \\
\hline 1 & Recount & Interesting & $3.51-4.00$ & Excellent & 6 texts \\
& & & $2.51-3.50$ & Good & 7 texts \\
& & & $1.51-2.50$ & Adequate & 2 texts \\
& & & $3.51-4.00$ & Excellent & 1 text \\
& & \multirow{2}{*}{ Socio-culturally appropriate } & $2.51-3.50$ & Good & 14 texts \\
& & & $3.51-4.00$ & Excellent & 2 texts
\end{tabular}


Up to date

Age-appropriate

Real-life

2 Narrative Interesting

Socio-culturally appropriate

Gender sensitive

Up to date

Age-appropriate

Real-life

3 Procedure Interesting

Socio-culturally appropriate

Gender sensitive

Up to date

Age-appropriate

Real-life
2.51-3.50 Good

2.51-3.50 Good

$3.51-4.00$

2.51-3.50

$3.51-4.00$

2.51-3.50

2.51-3.50

$1.51-2.50$

2.51-3.50

2.51-3.50

2.51-3.50

2.51-3.50

2.51-3.50

2.51-3.50

1.51-2.50

2.51-3.50

2.51-3.50

2.51-3.50

2.51-3.50

2.51-3.50
Excellent

Good

Excellent

Good

Good

Adequate

Good

Good

Good

Good

Good

Good

Adequate

Good

Good

Good

Good

Good
13 texts

15 texts

1 text

14 texts

2 texts

13 texts

14 texts

1 text

15 texts

15 texts

15 texts

15 texts

15 texts

8 texts

7 texts

15 texts

15 texts

15 texts

15 texts

15 texts

It can be seen that most of texts categorized excellent and good. A few texts are adequate. Mostly the texts are interesting for students. Interesting texts are near to the students. The most interesting text is recount texts. The interesting texts are up to date, relevant to students' life, relevant to students' age and relevant to students' socio-culture. The adequate texts are procedure texts, because the texts are bias, do not up to date and less relevant to students' life.

\section{DISCUSSION}

\section{The Readability of the Texts}

There were fourty five texts that analyzed. The texts were also analyzed based sub indicator of readability. They were lexical knowledge, background knowledge, syntactic appropriateness, discourse phenomena, organization and length of the texts. In term of lexical knowledge, most of the recount texts do not have many new lexical items. Then, in term of background knowledge, recount texts are suitable to students' background knowledge. Since recount consists of three kinds. They are personal, factual and bibliographical recount. The most suitable to students' background knowledge is personal recount. Such as text 1 had relevant to students' background knowledge. Since this text told about writer's experience when start to school, In term of background knowledge, the text related to students' background knowledge. It means that the text was excellent in background knowledge. The text was about students who went to Blue Mountains at their weekend. Text 8 also was suitable to students' background knowledge. It related to students background knowledge. The text was about lost in campground.

Moreover, text 9 was also suitable to students' background knowledge. The text was about students who were watching football match. The players of the football were their friends. Therefore, this text was closed to the students. In term of syntactic appropriateness, most of the 
texts had good syntactic appropriateness. Some texts such as text 3 , text 7 , text 8 , and text 10 had weak synttactic appropriateness. The syntactic appropriateness of the text 3 was weak. Since it had some mistake grammar such as "He is best known for his paintings. Almost every style in modern art is represented Picasso's works." Actually it should use "He was best known for his paintings. Almost every style in modern art was represented Picasso's works." And also in the last paragraph "Among his well-known cubbist paintings are "The Three Musicians" and "The Man with a guitar" which depict the destruction of a Spanish town." It should be "Among his well-known cubbist paintings were "The Three Musicians" and "The Man with a guitar" which depict the destruction of a Spanish town."

In term of organization, the texts were clearly organized. The organization of recount text includes the beginning, middle and ending. all of recount texts had good beginning, middle and endings.

In term of discourse phenomena, recount texts had good cohesiveness and coherence. It supported by the use of transition words in the paragraph of the texts.

The length of the texts, most of the texts were too short. Such as text1 had only 110 words. It less than the minimum words of a text as learning source. Text 3 , text 4 , text 5 ,text 6 , text 7 , text 8 , text 10 , text 12 , text 14 and text text 15 also had lack number of words.

In general, the readability of recount text was $26.67 \%$ was excellent, $66.67 \%$ was good and $6.67 \%$ was adequate. These findings showed that most of recount texts used by English teacher at SMAN 2 Sungai Tarab were suitable to the students.

The readability of narrative texts, in term of lexical knowledge, most of the recount texts do not have many new lexical items. Then, in term of background knowledge, narrative texts were not suitable to students' background knowledge. Since some of narrative texts were fable, legend and mith. Such as text 16 in term of background knowledge, the text was not suitable to students background knowledge. Since it was fable.

Then, in term of syntactic appropriateness, narrative texts were good. there was no mistake of grammar in narrative texts.

In discourse phenomena, it was indicated by cohesion words in the text. Narrative texts were good in discourse phenomena. Such as cohesion word in a sentence of text 16 "Then the Indian found he could leave him the wet grass all night, and pretty soon that fish could live in the shade whether the grass was wet or not."

The length of the text was good. Only a few number of narrative text had less than 200 words. Such as text 22 had only 175 words.

In general, narrative texts $46.67 \%$ was good, $53.33 \%$ was excellent in readability.

The readability of procedure text was good in readability. In term of lexical knowledge, procedure texts did not have a lot of new lexical items. In term of background knowledge, procedure texts were relevant to students' background knowledge. 
In term of syntactic appropriateness, procedure texts were good. The text used imperative sentence. Then, the discourse phenomena of procedure texts was also good. The texts had good cohesion. The lenght of procedure text was adequate. The texts had only more than 100 words and less than 200 words. In general, the readability of procedure texts was good.

\section{The Exploitability of the Texts}

This session discusses the second research problem that deals with the exploitability of reading texts. There were fifteen recount texts analyzed. Text 1 was good in exploitability. In term of lexical exploitability, the text was adequate. It means that the text introduces the new vocabulary did not use context clue. Such as I remember I had a naughty friend named Giant-O, because he was fat. In this sentence the content clue used was "because." It indicated cause and effect. It introduces the words "giant and fat." In structural exploitability the texts was good. It showed that the text was easy to be caught the meaning of the whole text by the students. In conclusion, text 1 had good exploitability.

Text 2 also excellent in exploitability. Text 2 had adequate lexical explotability. It showed by some sentences used context clues to introduce new vocabularies. Such as the text used restatement byusing commas : My older sister, Liza Minneli, introduced us in 1991. Then, Kevyn did my make-up for photo shoots with my sister and for the 1993 Tony Awards. But I will always remember the day we spent together in my bathroom. And the sentence "I asked him to come to Bloomingdale's with me, fully expecting him to say "No," but he said he'd love to and off we went." In term of structural exploitability, the text was good. Since it was easy to be gotten the idea of the text by the students.

Text 3 had poor in lexical exploitability. This text did not use context clue to introduce new vocabulary. Then, in structural exploitability, the text was adequate good. It means that the text had good exploitability.

Text 4 was adequate in lexical exploitability. The text had a sentence using context clue such as The unnamed 21-year-old woman was lucky to be only slightly injured in the incident, which occured late Sunday after she and her friends went up to the cage following an evening of drinking in a campsite in the town of Vacquires, officers said. This used modifier to introduce the incident that happen. In term of structural exploitability, the text was good. In conclusion, text 4 had adequate exploitability.

Text 5 was adequate in lexical exploitability. It had a sentence using context clue. It was "The problem, according to The Straits Times, was Mongkon looked every inch like a woman." It used modifier to indicate the context clue. Then, the structural exploitability of the text was adequate. Since to catch the meaning of the whole story was not easy by students. It can be concluded that text 5 was categorized adequate in exploitability.

Text 6 had adequate in lexical exploitability. It caused by only a sentence using context clue. The sentence was "Most times, I only ate once a day because I always had to rush and again it was difficult to find food." This text used cause effect to indicate context clue. Then, the structual exploitability of the text was good. The text could be gotten the meaning of the whole text by the students. 
Text 7 was adequate in lexical exploitability. It caused by only a sentence using context clue. The sentence was "This was a very long weekend but I enjoyed it a lot." This text used comparison contrast to indicate context clue. Then, the structual exploitability of the text was good. The text could be gotten the meaning of the whole text by the students. In conclusion, text 7 was adequate in exploitability.

Text 8 was good in lexical exploitability. It caused by only a sentence using context clue. The sentence was 'I was very scared, but I didn't tell how I felt to my men because I was afraid I would dampen their spirits and The air was so hot, but the ground was wet and muddy." This text used comparison contrast to indicate context clues. Then, the structual exploitability of the text was good. The text could be gotten the meaning of the whole text by the students. The text could be gotten the meaning of the whole text by the students. In conclusion, text 8 was good in exploitability.

Text 9 was good in lexical exploitability. It caused by only a sentence using context clue. The sentence was "He seemed very enthusiastic. However, the high school scored another goal. We were very sad and Then, one of the "bees" stopped the ball with one of his hands, so our team got the free kick." This text used comparison contrast to indicate context clues. Then, the structual exploitability of the text was good. The text could be gotten the meaning of the whole text by the students. The text could be gotten the meaning of the whole text by the students. In conclusion, text 9 was good in exploitability.

Text 10 was good in lexical exploitability. It caused by only a sentence using context clue. The sentence was "we stayed at Dirgahayu Hotel which is not far from Malioboro and We spent about two hours then. We were lucky because we were led by a smart and friendly guide." This text used comparison contrast to indicate context clues. Then, the structual exploitability of the text was good. The text could be gotten the meaning of the whole text by the students. The text could be gotten the meaning of the whole text by the students. In conclusion, text 10 was good in exploitability.

Text 11 was good in lexical exploitability. It caused by only a sentence using context clue. The sentence was "I tried to call my friend on my cell-phone, but the battery was running low. and I couldn't do anything but hope and pray and we spent about two hours then." This text used comparison contrast to indicate context clues. Then, the structual exploitability of the text was good. The text could be gotten the meaning of the whole text by the students. The text could be gotten the meaning of the whole text by the students. In conclusion, text 11 was good in exploitability.

Text 12 was adequate in lexical exploitability. It caused by only a sentence using context clue. The sentence was "it was getting darker and colder, so we built a fire camp" This text used comparison contrast to indicate context clues. Then, the structual exploitability of the text was good. The text could be gotten the meaning of the whole text by the students. The text could be gotten the meaning of the whole text by the students. In conclusion, text 12 was good in exploitability. 
Text 13 was adequate in excellent exploitability. It caused by four sentences of text 13 used context clues to introduce the vocabularies. Such Although I have read a lot about what to do during a flood, being in a flood for the first time was still a horrible experience and. Some people bravely walked through the water, while others used rafts to carry their belongings. This text used comparison contrast and cause and effect to indicate context clues. Then, the structual exploitability of the text was good. The text could be gotten the meaning of the whole text by the students. The text could be gotten the meaning of the whole text by the students. In conclusion, text 13 was good in exploitability.

Most of recount texts had good exploitability. $73.33 \%$ recount texts categorized good and $26.67 \%$ was adequate.

The exploitability of narrative text was good. Text 16 had excellent in lexical exploitability. The text had four context clues. Such as using modifier and comparison contrast. In term of structural exploitbaility, the text was easy to be gotten the whole meaning of the text by the students. Text 16 had moral value about if we have a pet, we must take care to our pet or we must pay attention to other human being around us.

Text 17 was adequate in lexical exploitability. It had only a sentence using context clue "But, since he had drunk the sacred water, his head was alive." In term of structural exploitability, the text was good. The moral value of this text was about we may not do something bad in this world,

Text 18 had good in lexical knowledge. It had two sentences using context clues. They are He was too big to fit inside the house, so his father built him a cradle to put in the water and When Paul Bunyan grew up, he decided to become a lumberjack, because he could fall an entire forest with one swing of his axe. The structural exploitability of the text was good. The moral value of text 18 was about keeping other people and human should help another human.

Text 19 had good exploitability. They are It was a surprised because there was some water inside the jug and The crow tried to push head into the jug, sadly, she found that the neck of the jug was too narrow, then, she tried to push the jug down for the water to flow out but she found the jug was too heavy. The structural exploitability of this text was also good. The moral value of text 19 was to be success need effort. It was like crow that worked hard to fill the water into the jug.

Text 20 was adequate in lexical exploitability. The text had only a sentence using context clue: We'll put her on a water-lily leaf in the middle of the stream so she won't be able to escape. In structural exploitability, the text was good. Then, moral value of the text was good.

In general, narrative text had good in exploitability.

Exploitability of procedure text was good. The text such as text 31 using example to indicate context clue, and text 42 . The context clues used such as using example (text 31 ), using definition (text 42).

\section{The Content Suitability of the Texts}


In terms suitability of content, based on the result of analysis format thirty one of the texts were categorized good, three texts were excellent and eleven texts were adequate. The texts that were adequate: text 3 , text 4 , text 5 .

Text 3 was not interesting because it was bibliographical recount and it told about bibliography of Picasso. Then, text 4 and text 5 were the factual recount. Therefore those texts were less interesting to the students. Most of procedure texts were talking about how to make meals. Actually when the meal is fried noodle, it was not really interesting, therefore it was categorized adequate.

The texts categorized excellent were text 9 , text 12 , and text 14 . Text 9 was about the football match between the writer school and another school team. This text was interesting since it really related to Senior High School students. Students are like story about the football match. Then, text 12 was about went camping. This text also can motivate students to read because most of students like the story about camping. The last was text 14 about students went to botanic garden. The story of this text was really to the students. Therefore this text was categorized excellent in indicator of content suitability.

Narrative texts consist of fable, legend and mith. Most of narrative text were interesting for the students. The texts were categorized good. Two texts were only adequate in content suitability. It means that the texts were less interesting.

The text such as text 18 was less interesting to the students. Since it was the story about Paul Bunyan and text text 20. It was the story about Thumbelina. It was less interesting to the students. suitbaility.

In general, $13.33 \%$ narrative text was adequate and $86.67 \%$ was good in content

Text 32 "Cheese Omelette" was not interesting to the students. Since it was usual done by the students. It was also so familiar to the students. Whenever it was not taught, the students also known how to make it. So, it was not really interesting to the students.

Then, text 33 "How to Mend a Puncture" was not interesting to the students. Since, the teachers gave information about how to mend a puncture bicycle. It could be said that this text was old texts. Since, Senior High School students did not use bicycle anymore. They used motorcycle. So the text told about mend the puncture in bicycle wheel was not relevant to the real situation today. Actually teachers should prepare the text that relevant to the modern situation.

\section{CONCLUSION}

Based on the findings of this research, it can be concluded that the analysis of reading materials is needed in order to know whether the reading materials is still good or not. Some the reading materials are not fulfilling the criteria of good text for Foreign language learners. Thus, it can be described as the following: personal recount was more readable than bibliographical and factual recount, some of the text is too short or the length of the text is not suitable for the students. Recount texts consist of personal, bibliographical and factual recount. The result of this 
report concludes that every reading text has strong and weak points. Commonly the reading texts have strong in readability, content suitability and exploitability. Some of the texts are categorized adequate. They were mostly procedure texts. Since some of procedure texts only told about how to make cheese omelet, how to make fried noodle, how to make tomato soup, how to make egg lemon soup and how to boil an egg.

\section{REFERENCES}

Alyousef, H.E. 2005. Teaching reading comprehension to ESL/EFL learners. The Reading Matrix. Vol. 5, No.2. pp:143-154

Arya, D.J, E. Hiebert \& P. Pearson. 2011. The Effect of Syntactic and Lexical Complexity on the Comprehension of Elementary Science Texts. International Electronic Journal Elementary Education. Vol. 4, no.1, pp:107-125

Barrot, J.S. 2004. Revisiting the role of linguistic complexity in ESL reading comprehension. The Southeast Asian Journal of Englihs Language Studies. Vol.9, no. 1, pp:5-16

Brown, J. D. 1995. The Elements of Language Curriculum. Boston: Heinle\& Heinle Publisher

Chou, P.T. 2011. The Effect of Vocabulary Knowledge and Background Knowledge on Reading Comprehension of Taiwanese EFL Students. Electronic Journal of Foreign Language Teaching. Vol.8, No.1, pp:108-115

Craint, Stephen and D. Shankweilert. 1986. Syntactic Complexity and Reading Comprehension. Status Report on Speech Research. Vol.86, no 87. pp:199-221

Day, Richard. 1994. Selecting a Passage for the EFL Reading Class. Forum Journal. Vol. 32 No.1 pp:20-30

Ebrahimi, N.A and Rahimi, Ali. 2013. Towards a more Efficient EFL Reading Comprehension Classroom Environment: The Role of Content and Critical Reading. Apples-Journal of Applied Language Studies. Vol.7, No.2, pp:1-15

Fulcher, Glenn. 1997. Text Difficulty and Accessibility: Reading Formulae and Expert Judgement. System. Vol.25, No.4, pp:497-513

Hetherington, Anne. 1985. Assessing the Suitability if Reading Materials for ESL Students. TESL Canada Journal. Vol. 3, No.1, pp. 37-52

Hirsh, David and P. Nation. 1992. What vocabulary size is needed to read unsimplified texts for Pleasure? Reading in a Foreign Language, Vol. 8, No. 2, pp:689-696

Kasule, Daniel. 2011. Textbook Readability and ESL Learners. Reading and Writing. Vol.1, No.2, pp:63-76 
Ling, Y. C. Et al. 2012. Evaluating the ESL Reading Texts for Intermediate Learners of English from the Perspective of Students. Global Journal of Human Social Science, Vol. 12, Issue. 7 , pp. 54-60

McKay, S.L. 2000. Teaching English as an International Language:Implications for Cultural Materials in the Classroom. TESOL Journal. Vol.9, Issue.4, pp:7-11

Moser, G.P and T.G.Morrison. 1998. Increasing Students' Achievement and Interest in Reading. Reading Horrizons. Vol.38, No.4, pp:233-245

Munir, Sirajul. 2013. An evaluation of reading comprehension textbooks taught at the English education department of islamic higher education in West Sumatera. LANGUAGE CYRCLE Journal of Language and Literature. Vol.VII, No. 2, pp:1-15

Richard, J. C. 2001. Curriculum Development in Language Teaching. Cambridge: Cambridge University Press

Ocak, Gurbuz. 2010. The Student Attitudes in Terms of the Usage of English Activities and Materials and Their Contributions to English Learning Process. Turkey: Elsevier Ltd

Sasson, Dorit. 2007.Six Tips Teaching Lower Level Junior High School ESL Studdents. The Internet TESL Journal. Vol. XIII, No. 7

Sulistyorini, Heni. 2006. Tingkat Keterbacaan teks dan pengaruhnya terhadap prestasi belajar siswa. Semarang: Unpublished Thesis

Wassman, Rose and L.A Rinsky. 2000. Effective Reading in a Changing Word. London:Prentice-Hall International

Zainil. 2008. Actional Functional Model (AFM)teacher's guide for intermediate students. Padang: Sukabina Press 